\title{
Monitoring and Visualization of Tropospheric Ozone in Rural/Semi Rural Sites of Rawalpindi and Islamabad, Pakistan
}

\author{
Sheikh Saeed Ahmad ${ }^{1}$, Neelam Aziz ${ }^{1} \&$ Noreen Fatima ${ }^{1}$ \\ ${ }^{1}$ Department of Environmental Sciences, Fatima Jinnah Women University, Rawalpindi, Pakistan \\ Correspondence: Sheikh Saeed Ahmad, Department of Environmental Sciences, Fatima Jinnah Women \\ University, Rawalpindi, Pakistan. Tel: 92-321-516-7726. Email: drsaeed@fjwu.edu.pk
}

Received: March 5, 2012

Accepted: March 31, 2012 Online Published: June 14, 2012

doi:10.5539/ep.v1n2p75

URL: http://dx.doi.org/10.5539/ep.v1n2p75

\begin{abstract}
Ozone is one of the most pervasive of the global air pollutants, with impacts on human health, food production and the environment. Present research highlights emphasized the main rural agricultural areas of Rawalpindi and Islamabad for their air quality assessment and visualization in order to evaluate and predict the risk areas to facilitate farmers and policy makers to draft critical guidelines for possible threat of ozone concentrations to the agricultural sector of country in the coming years. Model 400E ozone analyzer was used to determine the ozone concentration. Mean concentration value of $\mathrm{O}_{3}$ recorded during the campaign is $35 \mathrm{ppb}$ in Rawalpindi and Islamabad. Seasonal fluctuations in $\mathrm{O}_{3}$ concentration levels were also observed throughout the year in different months. This can be attributed to changing climatic variables i.e. temperature, rainfall and humidity throughout the different season. Climatological parameters also showed significant association with ozone concentration. Comparison of obtained values of ozone with the WHO standards indicates that $\mathrm{O}_{3}$ levels are still lower than standards. This indicates that we still have a time to reconsider our anthropogenic activities to control the $\mathrm{O}_{3}$ precursors to prevent any deleterious effects on agricultural sector.
\end{abstract}

Keywords: ozone concentration, Model 400E ozone analyzer, climatic variables, semi-rural/rural areas, Rawalpindi and Islamabad, Pakistan

\section{Introduction}

Clean air is considered to be a basic requirement for healthy life. But, continuously increasing air pollution around the world is posing great threat to both human health and environment. $\mathrm{O}_{3}$ is the main component of photochemical smog and third most important green house gas (Percy \& Ferretti, 2004; Vingarzan, 2004). $\mathrm{O}_{3}$ is a secondary air pollutant, produced by photochemical reaction, involving nitrogen oxides $\left(\mathrm{NO}_{\mathrm{x}}\right)$, carbon monoxide (CO) and volatile organic compounds (VOC) (including $\mathrm{CH}_{4}$ ). These precursors largely contributed by anthropogenic activities i.e. combustion in industries, vehicles and for domestic purposes. The $\mathrm{O}_{3}$ precursor's breadth, the role of natural and physical process in distribution of $\mathrm{O}_{3}$, production and destruction and complex chemical reaction makes the management of $\mathrm{O}_{3}$ quite difficult.

$\mathrm{O}_{3}$ is increasing at a greater pace due to the increase in anthropogenic precursor emissions (Sitch, Cox, Collins, \& Huntingfor, 2007). It has been estimated that the increase in $\mathrm{O}_{3}$ concentrations is between 0.5 and $2 \%$ per year (Vingarzan, 2004), and that by 2100 the mean monthly 24-h concentration will be above $40 \mathrm{ppb}$ over most of the Earth, and above $70 \mathrm{ppb}$ over some regions (Sitch, Cox, Collins, \& Huntingfor, 2007 ). Currently, $\mathrm{O}_{3}$ is the most important pollutant in rural areas (Ashmore, 2005) due to long-range transport from polluted sites (Vingarzan, 2004). $\mathrm{O}_{3}$ is the most important pollutant with respect to the native vegetation and crops. It causes a visible injury and reduction in growth, series of harmful physiological and biochemical effects and altered sensitivity to biotic and abiotic stresses (Fuhrer, 2009; Calatayud et al., 2010; Pinto et al., 2010). Photochemical oxidant pollution has greatly reduced the economic yield of major agricultural crops (especially wheat and rice) which is well documented by Aunan, Berntsen and Seip (2000), Wahid et al. (2001) and Wahid (2006a, 2006b).

In contrast to developed countries like USA and European countries, little work is done on impact of air pollutants on agricultural crops in developing countries. In Pakistan number of studies has been conducted to study the impact of air pollutants on wheat, rice and soybean (major crops in Pakistan) (Wahid et al., 2001; Wahid, 2006a, 2006b). The results indicated 30-70\% reduction in yield as compared to the control plants. But still not much information is available on urban, suburban and rural arable productive areas, phytotoxic pollutant 
concentration in Pakistan. And also there is no proper pollution control system due to technical, economical limitations and other reasons. As a result toxic pollutant concentration is continuously rising in Pakistan may lead to deleterious effects on agriculture sector in future, so it's extremely important take serious notice and actions of this alarming situation.

Air pollution mapping is a valuable tool for the monitoring and management of the air quality. It manages both the statistical and spatial data and enables to show the relationship between poor air quality and frequency of deficient human and environmental health (ESRI, 2007). That will help in taking steps to control emissions. Number of studies has been carried on air pollution in conjunction with GIS (Veen et al., 2010; Elbir el al., 2010; Ahmad, Büker, Emberson, \& Shabbir, 2011).

In this project ozone concentration is monitored and visualized through GIS in twin cities of Pakistan in order to evaluate and predict the risk areas to facilitate local farmers and policy makers to draft critical guidelines for possible threat of ozone concentrations to the cash crops, sustainability and food security of country in the coming years.

\section{Materials and Methods}

\subsection{Study Area}

Islamabad and Rawalpindi are commonly viewed as one unit. The two cities, which are $15 \mathrm{~km}$ apart, are effectively a single mega town. Islamabad is the capital of Pakistan. Both are located in the Pothwar Plateau in the northwest of country. Twin cities are located at $33^{\circ} 40^{\prime} \mathrm{N} 73^{\circ} 10^{\prime} \mathrm{E}$. total population is over 4.5 million inhabitants. Rapid growth of both Islamabad and Rawalpindi has made ever increasing demands on natural resources and caused adverse effects on the environment (Sheikh et al., 2007). A map of study area is shown in Figure 1. Agriculture after industries in Islamabad and Rawalpindi is one of the main ingredients of whole area's economy. The total rural area of Islamabad and Rawalpindi comprises of $446.20 \mathrm{~km}^{2}$ and $259 \mathrm{~km}^{2}$ respectively. Besides common vegetables, Rabi and Kharif crops including Rice, Wheat, Maize and Bajra are the major crops grown here. Peaches, groundnuts, apricots, plums, citrus apples, olives, pears and walnuts are the common fruits grown.
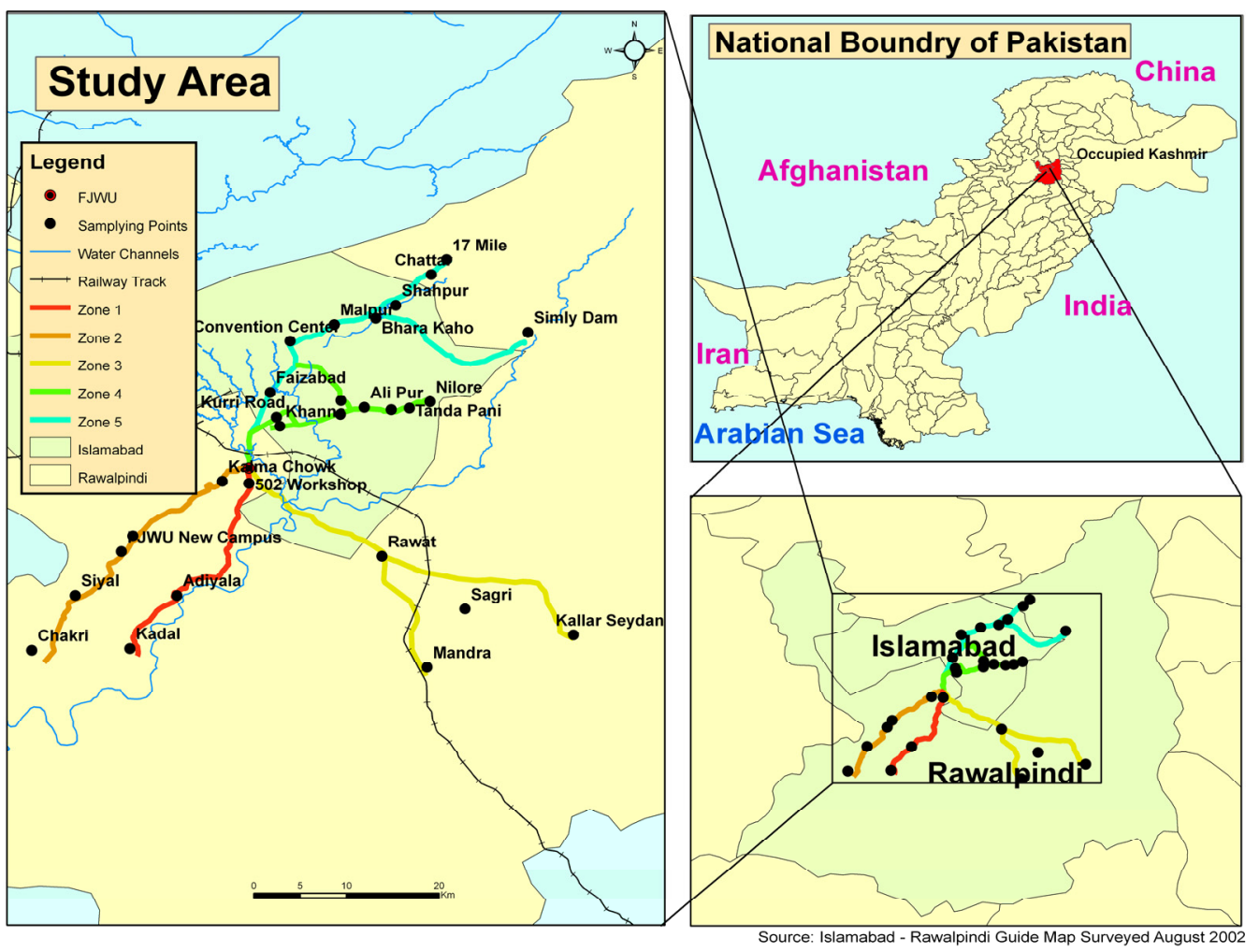

Figure 1. Base Map 
Based upon geographical locations of Rawalpindi / Islamabad the study area is divided into five main zones with zero point (FJWU) as a reference point. We have selected zero point as a reference position because it is an essential passing way for many routes in/out of the twin cities and have high traffic flux in the regions of under consideration. Similarly these areas are located in the form of concentric rings assuming zero point as central hub. It will also help to find spatial correlation in different agricultural fields under study. Boundaries of each zone are defined within the $40 \mathrm{~km}$ of reference point. $40 \mathrm{~km}$ distance is chosen based on previous studies in this domain. The clear demarcation of rural/semi-rural and surrounding areas are as under (within $40 \mathrm{~km}$ from zero point).

Zone 1: 502 workshop, Adyala village, Kadal

Zone 2: Kalma Chowk, Pir Mehr Ali Shah Town, FJWU New Campus, Siyal and Chakri

Zone 3: Rawat, Kallar, Sagri and Mandra

Zone 4: Kuri, Khanna, Tarlahi, Alipur, Jhangi Syedan, Thanda Pani, Nelore and Chakshahzad

Zone 5: Convention Center, Malpur, Bara khau, Shahpur Village, Chattar, 17 Mile and Samli Dam

\subsection{Ozone Determination}

The Model 400E ozone analyzer (microprocessor-controlled analyzer that determines the concentration of ozone $\left(\mathrm{O}_{3}\right)$ in a sample gas drawn through the instrument) was used to measure the ozone concentrations. It requires that sample and calibration gases be supplied at ambient atmospheric pressure in order to establish a stable gas flow through the absorption tube where the gas' ability to absorb ultraviolet (UV) radiation of a certain wavelength (in this case $254 \mathrm{~nm}$ ) is measured. Calibration of the instrument is performed in software and does not require physical adjustments to the instrument. During calibration, the microprocessor measures the current state of the UV Sensor output and various other physical parameters of the instrument and stores them in memory. This concentration value and the original information from which it was calculated are stored in one of the unit's Internal Data Acquisition System as well as reported to the user via a Front Panel $\backslash$ Display or a variety of digital and analog signal outputs. The basic principle by which the Model 400E Ozone Analyzer works is called Beer's Law (also referred to as the Beer-Lambert equation). It defines the how light of a specific wavelength is absorbed by a particular gas molecule over a certain distance at a given temperature and pressure.

\subsection{Spatial Modeling and Surface Interpolation through IDW}

GIS is a very powerful tool for air quality management. Though there are large numbers of spatial modeling techniques regarding the applications of GIS but surface interpolation through IDW (Inverse Distance Weight age) was used in this present study to demarcate the locational distribution of $\mathrm{O}_{3}$. This method used defined and selected set of sample points for estimating the output grid cell values. It determined the cell value using a linearly weighted combination of set of sample points and controls the importance of the known points upon the interpolated values based on their distance from the output points there by generating a surface grid. Hence surface grids or layers of $\mathrm{O}_{3}$ were generated using spatial analyst tool bar considering sampling points as a source.

\subsection{Metrological Data}

Metrological parameters like temperature, relative humidity and precipitation has also been collected from Pakistan Metrological Department to study the effects of these parameters on air pollutant concentration.

\section{Results and Discussion}

\subsection{Data Analysis}

The data used for this research project were gathered from 28 different sites, divided into 5 zones in Rawalpindi and Islamabad as mentioned in the previous section. Tables 1 and 2 showed the monthly concentration levels of $\mathrm{O}_{3}$ measured at these different locations. 
Table 1. Monthly mean values of $\mathrm{O}_{3}$ of all sites in 5 zones of semi-rural areas of Rawalpindi and Islamabad during January to September 2010

\begin{tabular}{|c|c|c|c|c|c|c|c|c|c|}
\hline Months & Jan-10 & Feb-10 & Mar-10 & Apr-10 & May-10 & Jun-10 & Jul-10 & Aug-10 & Sep-10 \\
\hline Sampling Sites & \multicolumn{9}{|c|}{ Tropospheric Ozone Concentration (ppb) } \\
\hline \multicolumn{10}{|l|}{ Zone 1} \\
\hline 502 Workshop & 26.08 & 27.96 & 40.67 & 41.72 & 42.32 & 41.23 & 29.45 & 27.45 & 33.07 \\
\hline Adyala Village & 23.84 & 25.79 & 39.44 & 41.59 & 42.34 & 41.46 & 27.56 & 26.89 & 32.48 \\
\hline Kadal & 28.53 & 29.03 & 41.51 & 42.38 & 43.66 & 42.64 & 29.65 & 28.01 & 34.12 \\
\hline \multicolumn{10}{|l|}{ Zone 2} \\
\hline Kalma Chowk & 27.87 & 29.01 & 41.02 & 43.11 & 42.85 & 41.14 & 29.01 & 27.55 & 34.69 \\
\hline Pir Mehr Ali Shah Town & 26 & 28.22 & 42.64 & 43.81 & 43.74 & 42.57 & 28.89 & 26.92 & 35.31 \\
\hline FJWU New Campus & 28.01 & 29.46 & 42.89 & 43.76 & 43.18 & 42.65 & 29.65 & 27.12 & 36.96 \\
\hline Siyal & 27.34 & 28.06 & 41.24 & 42.66 & 41.97 & 41.03 & 27.01 & 26.24 & 34.54 \\
\hline Chakri & 27.94 & 29.54 & 42.65 & 43.69 & 42.43 & 41.17 & 27.83 & 26 & 34.06 \\
\hline \multicolumn{10}{|l|}{ Zone 3} \\
\hline Rawat & 26.76 & 28.78 & 41.95 & 42.78 & 43.07 & 41.69 & 28.46 & 26.05 & 33.46 \\
\hline Kallar & 26.98 & 28 & 42.76 & 43.56 & 43.36 & 42.38 & 27.76 & 26.32 & 34.23 \\
\hline Sagri & 25.35 & 28.34 & 41.98 & 43.09 & 42.99 & 41.87 & 28.24 & 26.87 & 33.36 \\
\hline Mandra & 27.78 & 28.06 & 42.89 & 43.98 & 43.65 & 41.62 & 27.04 & 25.76 & 34.04 \\
\hline \multicolumn{10}{|l|}{ Zone 4} \\
\hline Kuri & 26.34 & 27.85 & 42.16 & 42.82 & 42.51 & 41.67 & 27.02 & 26.08 & 33.76 \\
\hline Khanna & 26.89 & 27.93 & 42.98 & 43.89 & 43.67 & 42.67 & 27.67 & 25.87 & 33.53 \\
\hline Tarlahi & 27.87 & 29 & 42.76 & 43.01 & 43.24 & 42.65 & 28.67 & 26.54 & 35.03 \\
\hline Ali Pur & 28.01 & 29.98 & 43.54 & 44.34 & 44.24 & 43.29 & 29.34 & 27.24 & 34.45 \\
\hline Jhangi Syedan & 26.54 & 28.54 & 42.64 & 43.65 & 43.54 & 42.63 & 27.64 & 25.93 & 33.87 \\
\hline Thanda Pani & 27 & 29.34 & 41.99 & 42.85 & 42.75 & 41.56 & 29.98 & 27.15 & 34.09 \\
\hline Nelore & 28.18 & 29.35 & 41.35 & 42.12 & 42.36 & 41.15 & 29.05 & 27.63 & 34.09 \\
\hline Chakshahzad & 28.03 & 29.35 & 42.55 & 43.32 & 43.45 & 42.65 & 29.07 & 27.65 & 35.8 \\
\hline \multicolumn{10}{|l|}{ Zone 5} \\
\hline Faizabad & 27.32 & 28.65 & 43.67 & 44.67 & 44.56 & 43.26 & 28.02 & 26.04 & 35.54 \\
\hline Convention Centre & 27.34 & 28.51 & 40.82 & 42.63 & 42.15 & 41.14 & 28.01 & 27.55 & 35.39 \\
\hline Malpur & 25.04 & 27.59 & 40.94 & 41.79 & 42.04 & 41.86 & 26.86 & 25.49 & 32.87 \\
\hline Bara khau & 27.93 & 29.13 & 41.71 & 42.68 & 43.6 & 42.94 & 28.55 & 28.1 & 34 \\
\hline Shahpur Village & 25.34 & 26.85 & 40.86 & 41.62 & 42.41 & 41.38 & 28.02 & 26.18 & 33.85 \\
\hline Chattar & 26.85 & 27.62 & 41.4 & 42.81 & 42.44 & 41.57 & 27.49 & 26.32 & 34.71 \\
\hline 17 Mile & 27.11 & 28.64 & 42.09 & 43.16 & 43.1 & 42.07 & 29.05 & 28.82 & 36.06 \\
\hline Samli Dam & 27.1 & 28.36 & 41.34 & 42.08 & 41.87 & 40.63 & 28.11 & 27.14 & 33.74 \\
\hline
\end{tabular}


Table 2. Monthly mean values of $\mathrm{O}_{3}$ of all sites in 5 zones of semi-rural areas of Rawalpindi and Islamabad during October 2010 to May 2011 and average $\mathrm{O}_{3}$ conc. of all sites with standard deviation/error from January 10 to May 2011

\begin{tabular}{|c|c|c|c|c|c|c|c|c|c|c|}
\hline Months & 10-Oct & 10-Nov & 10-Dec & 11-Jan & 11-Feb & 11-Mar & 11-Apr & 11-May & Average & SD \\
\hline Sampling Sites & \multicolumn{10}{|c|}{ Tropospheric Ozone Concentration (ppb) } \\
\hline \multicolumn{11}{|l|}{ Zone 1} \\
\hline 502 Workshop & 33.05 & 27.65 & 25.01 & 28 & 29.86 & 41.03 & 42.56 & 42.32 & 34.08 & 7 \\
\hline Adyala Village & 32.33 & 26.88 & 25.59 & 28.54 & 30.12 & 42.41 & 43.75 & 43.45 & 33.79 & 8 \\
\hline Kadal & 33.98 & 28.09 & 26.23 & 28.56 & 29.98 & 43.54 & 44.35 & 44.03 & 35.19 & 7 \\
\hline \multicolumn{11}{|l|}{ Zone 2} \\
\hline Kalma Chowk & 35 & 28.45 & 26.03 & 27 & 28.26 & 42.31 & 43.11 & 43 & 34.67 & 7 \\
\hline Pir Mehr Ali Shah Town & 34.94 & 29.14 & 27.87 & 27.85 & 29.86 & 41.96 & 42.99 & 43.06 & 35.05 & 7 \\
\hline FJWU New Campus & 36.56 & 27.87 & 26.32 & 28.11 & 29.65 & 43.95 & 44.45 & 43.54 & 35.54 & 7 \\
\hline Siyal & 35.22 & 26.76 & 25.89 & 27.46 & 28.99 & 42.85 & 43.65 & 43.15 & 34.36 & 7 \\
\hline Chakri & 33.67 & 27.15 & 26.76 & 28 & 29.75 & 41.56 & 43 & 42.96 & 34.60 & 7 \\
\hline \multicolumn{11}{|l|}{ Zone 3} \\
\hline Rawat & 34.11 & 27.62 & 25.98 & 27.45 & 29 & 43.34 & 44.39 & 44.18 & 34.65 & 8 \\
\hline Kallar & 35.06 & 27.68 & 26.76 & 27.23 & 29.24 & 42.62 & 43.56 & 43.49 & 34.76 & 8 \\
\hline Sagri & 34 & 26.35 & 25.18 & 27.15 & 29.04 & 43.04 & 44.33 & 44.29 & 34.44 & 8 \\
\hline Mandra & 34.23 & 27.51 & 25.03 & 27.69 & 28.19 & 41.56 & 42.56 & 42.87 & 34.38 & 8 \\
\hline \multicolumn{11}{|l|}{ Zone 4} \\
\hline Kuri & 34.02 & 27.56 & 26.07 & 27.35 & 28.41 & 41.87 & 42.08 & 42.26 & 34.11 & 7 \\
\hline Khanna & 34.44 & 27 & 26.07 & 27 & 28.11 & 42.6 & 43.65 & 43.03 & 34.53 & 8 \\
\hline Tarlahi & 35.34 & 26.5 & 25.98 & 26.67 & 28.64 & 43.16 & 43.71 & 43.74 & 34.85 & 8 \\
\hline Ali Pur & 34.24 & 27.55 & 26.46 & 28.51 & 29.48 & 42.94 & 44.04 & 44.56 & 35.42 & 8 \\
\hline Jhangi Syedan & 33.76 & 26.39 & 24.98 & 27.04 & 28.32 & 42.64 & 42.95 & 43.66 & 34.40 & 8 \\
\hline Thanda Pani & 34.61 & 26.06 & 26.07 & 28.65 & 29.85 & 42.99 & 43.15 & 43.75 & 34.81 & 7 \\
\hline Nelore & 33.65 & 26.65 & 25.18 & 28.16 & 29.55 & 43.03 & 43.56 & 42.72 & 34.58 & 7 \\
\hline Chakshahzad & 35.08 & 27.87 & 25.78 & 28.93 & 29.37 & 42.13 & 43.28 & 43.85 & 35.19 & 7 \\
\hline \multicolumn{11}{|l|}{ Zone 5} \\
\hline Faizabad & 36.11 & 28.65 & 27.7 & 26.56 & 28.99 & 43.31 & 44.98 & 44.45 & 35.44 & 8 \\
\hline Convention Centre & 36.12 & 28.05 & 27.13 & 27.45 & 29.26 & 43.21 & 44.1 & 43.23 & 34.83 & 7 \\
\hline Malpur & 33.43 & 26.68 & 25.66 & 26.54 & 28.12 & 42.61 & 43.5 & 43.38 & 33.79 & 8 \\
\hline Bara khau & 34.46 & 28.2 & 27.45 & 27.34 & 29.38 & 42.64 & 43.35 & 43.03 & 34.97 & 7 \\
\hline Shahpur Village & 33.76 & 26.56 & 24.98 & 27.46 & 29.01 & 41.56 & 42.98 & 42.35 & 33.83 & 7 \\
\hline Chattar & 35.09 & 28.54 & 26.4 & 26.05 & 28.55 & 42.76 & 43.69 & 42.76 & 34.41 & 7 \\
\hline 17 Mile & 36.96 & 27.87 & 26.32 & 27.16 & 29.5 & 43.85 & 44.65 & 43.34 & 35.28 & 7 \\
\hline Samli Dam & 34.62 & 28.16 & 28.09 & 26.56 & 28.09 & 42.65 & 43.45 & 42.56 & 34.39 & 7 \\
\hline
\end{tabular}

As mentioned earlier, the sites have been divided in to five zones. The comparison among different sites in each zone was separately taken into account. Table 1 shows that zone 1 contained three sites i.e. 502 Workshop, Adyala Village and Kadal. It was found that the highest mean $\mathrm{O}_{3}$ concentration area in zone 1 was Kadal, which is a rural area and lowest mean $\mathrm{O}_{3}$ concentration area in zone 1 was 502 Workshop, which is an urban area. 
Table 1 shows a plot of mean concentration of $\mathrm{O}_{3}$ in zone 2. Five sites which were selected in zone 2 including Kalma Chowk, Pir Mehr Ali Shah Town, FJWU New Campus, Siyal and Chakri. From table it can be seen that FJWU New Campus showed the highest mean $\mathrm{O}_{3}$ concentration in zone 2.

Table 1 shows a plot of mean concentration of $\mathrm{O}_{3}$ in zone 3 with a total of four different sites. These sites were Rawat, Kallar, Sagri and Mandra. Mean concentration of $\mathrm{O}_{3}$ was same at all the four sites.

Table 1 shows a comparison of eight different sites in zone 4 for mean $\mathrm{O}_{3}$ concentration. These sites include Kuri, Khanna, Tarlahi, Ali Pur, Jhangi Syedan, Thanda Pani, Nelore Ali pur and Chakshahzad had highest $\mathrm{O}_{3}$ concentration and Chakshahzad, while other sites show similar concentration level.

Zone 5 also contains eight sites and comparison of these sites is shown in table (1). The sites were Faizabad, Convention Centre, Malpur, Bara Khau, Shahpur Village, Chattar, 17 Mile and Samli dam. It can be clearly seen from the table that Malpur and Shahpur village had lowest concentration of ozone, while 17 Mile and Faizabad had highest concentration of ozone.

\subsection{Monthly Trends in $\mathrm{O}_{3}$ Concentration Levels}

The variation of ozone concentration can be considerably, on a daily, a seasonal or yearly basis. Most of these temporal variations can be explained by the weather conditions. Howe ever, variation on regional or local scale is also attributed to the influence of local pollution and to local deposition climate. Whisker box plot is used to display the seasonal trends of ozone throughout the experimental period. The box-and-whisker plot is an exploratory graphic, used to show the distribution of a dataset. A box-and-whisker plot displays the mean, quartiles, and minimum and maximum observations for a group. Figure 2 shows a plot of mean $\mathrm{O}_{3}$ concentration of all the five zones to understand the general trends of $\mathrm{O}_{3}$ concentration levels in different months.

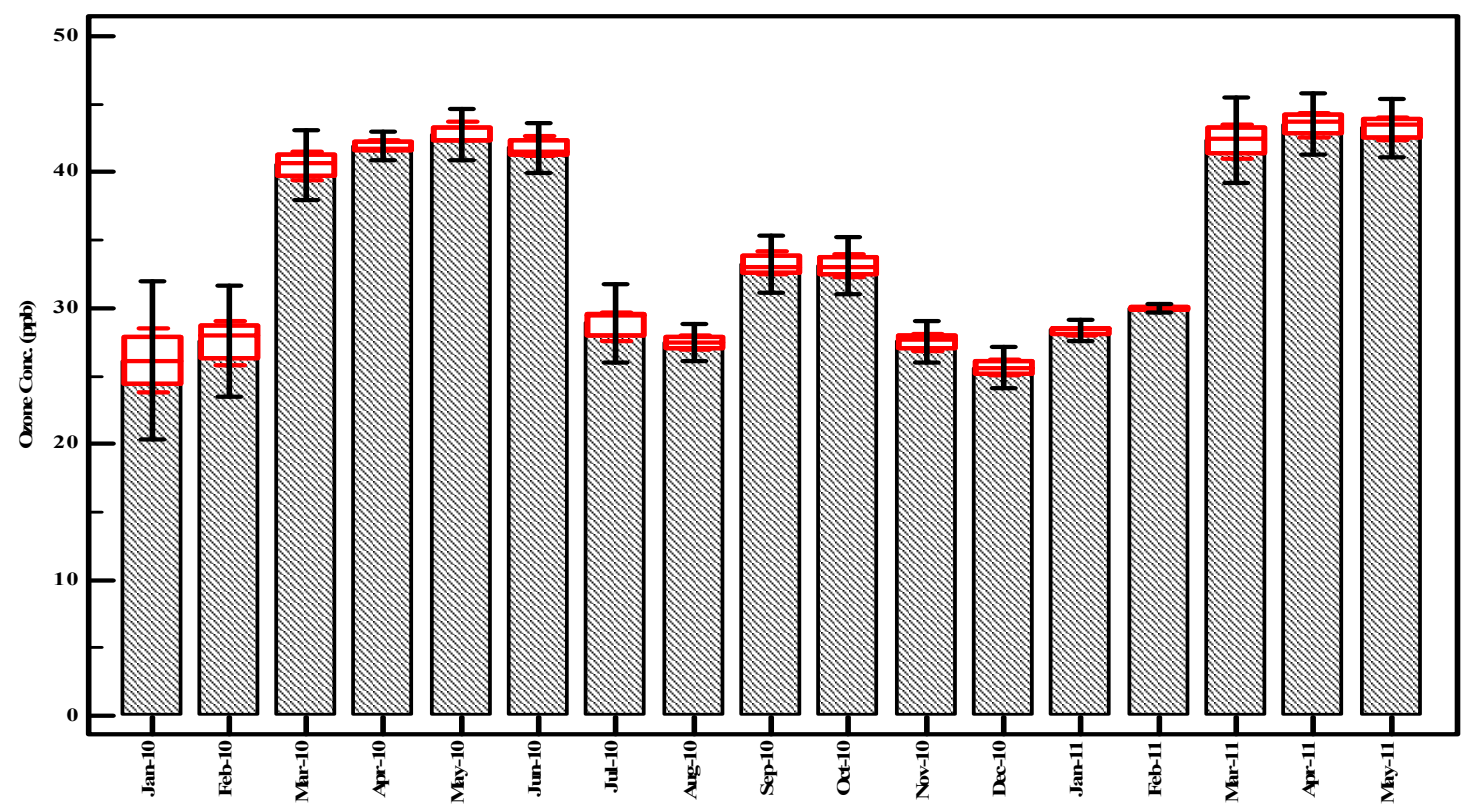

Figure 2. Monthly variations in $\mathrm{O}_{3}$ concentrations level (January 2010 - May 2011)

It can be seen that $\mathrm{O}_{3}$ concentration levels fluctuate throughout the year in different months. The low concentration values of $\mathrm{O}_{3}$ were recorded in December and January (winters) and July and August (monsoon), while the high concentration values were recorded in May and June (summers) (Figure 2). As traffic emission is the predominate source of $\mathrm{O}_{3}$ precursors, leading to more or less constant $\mathrm{O}_{3}$ concentration levels throughout the year. Though, slightly higher levels of $\mathrm{O}_{3}$ concentration can be attributed to the higher solar radiation intensity in summer season which enhanced the photolytic reactions tends to break down the $\mathrm{NO}_{\mathrm{x}}$ into $\mathrm{O}_{3}$ leading to higher $\mathrm{O}_{3}$ levels. While in winter due to reduced solar radiations, $\mathrm{NO}_{\mathrm{x}}$ tends to accumulate and $\mathrm{O}_{3}$ concentration levels were lowered in the atmosphere.

Number of studies conducted on the fluctuation of $\mathrm{O}_{3}$ concentration levels throughout the year indicates the similar results. In Spain $\mathrm{O}_{3}$ concentration levels were measured from January to December 2007. Results show the highest concentration values of $\mathrm{O}_{3}$ in summer and minimum values in winters (Martin et al., 2010). In a study 
carried out in urban Spain, the mean concentration value of $\mathrm{O}_{3}$ was calculated from January to December 2007. During 2003-2004, SUPARCO, the Pakistan Space and Upper Atmosphere Research Commission conducted a yearlong baseline air quality study in country's major urban areas i.e. Karachi, Lahore, Quetta, Peshawar, Rawalpindi and Islamabad. Results indicated ozone highest levels in summer and spring while lower were observed in winter and monsoon. The average concentration value of $\mathrm{O}_{3}$ in urban areas of Rawalpindi and Islamabad was calculated to be $17.46 \mathrm{ppb}$ and $17.7 \mathrm{ppb}$ respectively (Ghauri, Lodhi, \& Mansha, 2007).

\subsection{Relationship with Meteorological Variables}

Attempts were made to relate monthly mean $\mathrm{O}_{3}$ concentrations with the climatological variables such as temperature (measured in degree Celsius), relative humidity (RH in \%) and rain fall (measured in mm) (supplied by Islamabad meteorological Department).

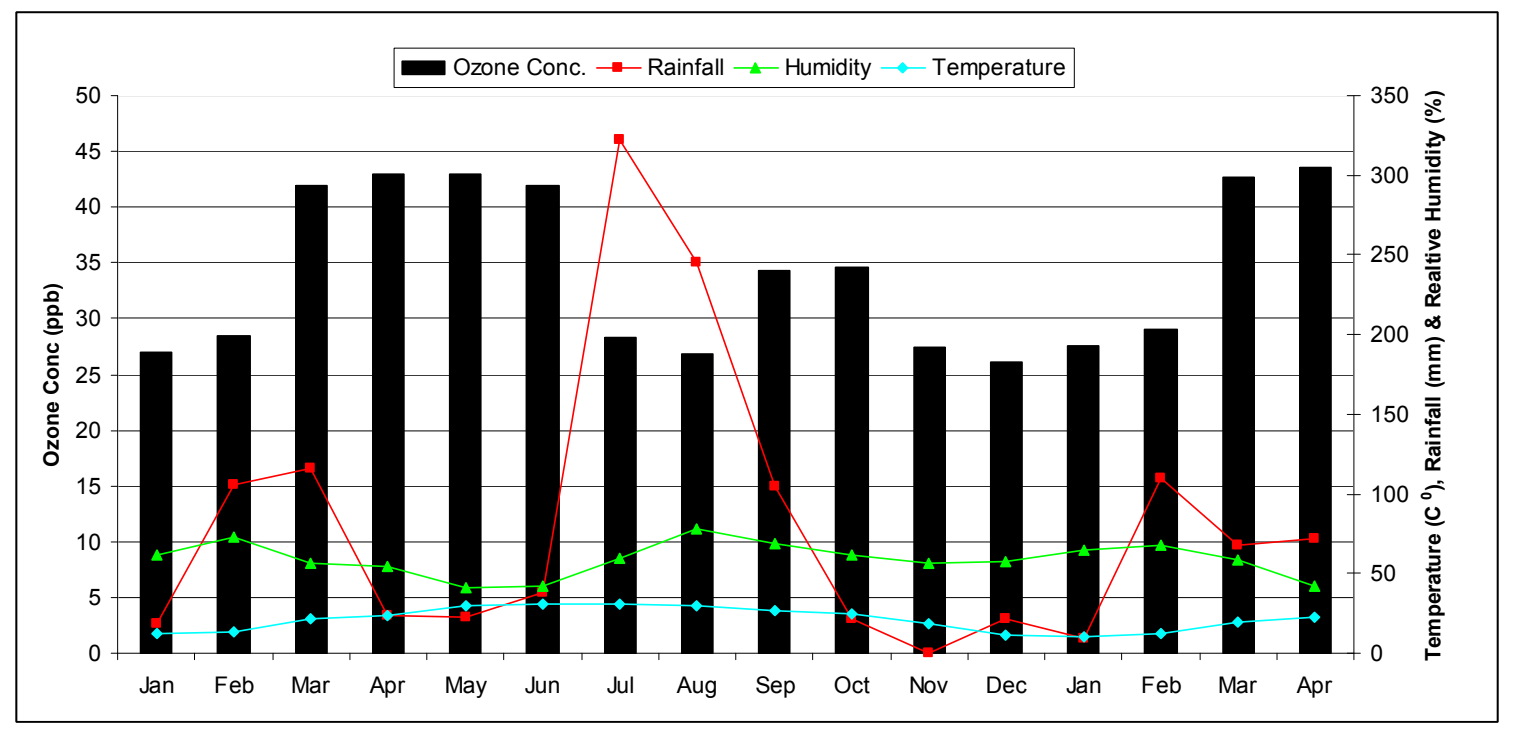

Figure 3. Relationship between $\mathrm{O}_{3}$ concentration and climatic variables

Figure 3 depicted that the ozone concentration level is negatively related to the relative humidity (RH in \%) and positively related to temperature (in ${ }^{\circ} \mathrm{C}$ ). Periods with higher temperature and lower humidity usually lead to the higher level of ozone in the atmosphere and vice versa. This can again be attributed to the fact as indicated above that during summer as a result of increase solar radiation, $\mathrm{NO}_{\mathrm{x}}$ tend to photolysed and increase the $\mathrm{O} 3$ concentration levels in the atmosphere. Figure 3 also showed negative correlation of ozone concentration with rainfall (in $\mathrm{mm}$ ). Hence, in monsoon season i.e. from July to September the ozone concentration in the atmosphere decreased with increase in rate of rain fall due to dispersion and transportation of pollutants in the atmosphere leads to dilution of pollutants in the atmosphere. Similar relationship of ozone concentration levels with meteorological variables have previously been reported by Atkins and Lee (1995), Wahid et al. (1995a, 1995b) Chan, So, and Samad (2001), Ghauri, Lodhi, and Mansha (2007), Markovic et al. (2008), Shan et al. (2009) and Martin et al. (2010). Multiple regression analysis (Table 3) showed that ozone concentration is greatly influenced by the independent climatic variables i.e. temperature $\left({ }^{\circ} \mathrm{C}\right)$, rainfall $(\mathrm{mm})$ and relative humidity $(\%)$. The correlation results indicated that ozone is positively related with temperature $(\mathrm{r}=0.4709)$ and negatively associated with rainfall $(r=-0.2333)$ and relative humidity $(r=-0.6999)$.

Table 3. Multiple Regression Analysis Regression Equation

\begin{tabular}{l|llll}
\hline Independent variables & Coefficient & Std. Error & $\mathrm{t}$ & $\mathrm{P}$ \\
\hline (Constant) & 45.8198 & & & \\
\hline Humidity & -0.3220 & 0.1682 & -1.914 & 0.0797 \\
\hline Rainfall & -0.01824 & 0.02159 & -0.845 & 0.4147 \\
\hline Temperature & 0.4152 & 0.2486 & 1.670 & 0.1207 \\
\hline
\end{tabular}


Zero order correlation coefficients

\begin{tabular}{cl}
\hline Variable & $\mathrm{R}$ \\
\hline Humidity & -0.6999 \\
Rainfall & -0.2333 \\
Temperature & 0.4709 \\
\hline
\end{tabular}

\subsection{Spatial Interpolation Map}

To get a better view of pollutant concentrations, the obtained values were spatially interpolated using the inverse distance weighted (IDW) method. Inverse distance weighting is the simplest interpolation method. Spatial interpolation maps for $\mathrm{O}_{3}$ have been developed by using ArcGIS 9.2 to visualize the higher pollutant concentration areas in Rawalpindi and Islamabad (Figure 4).

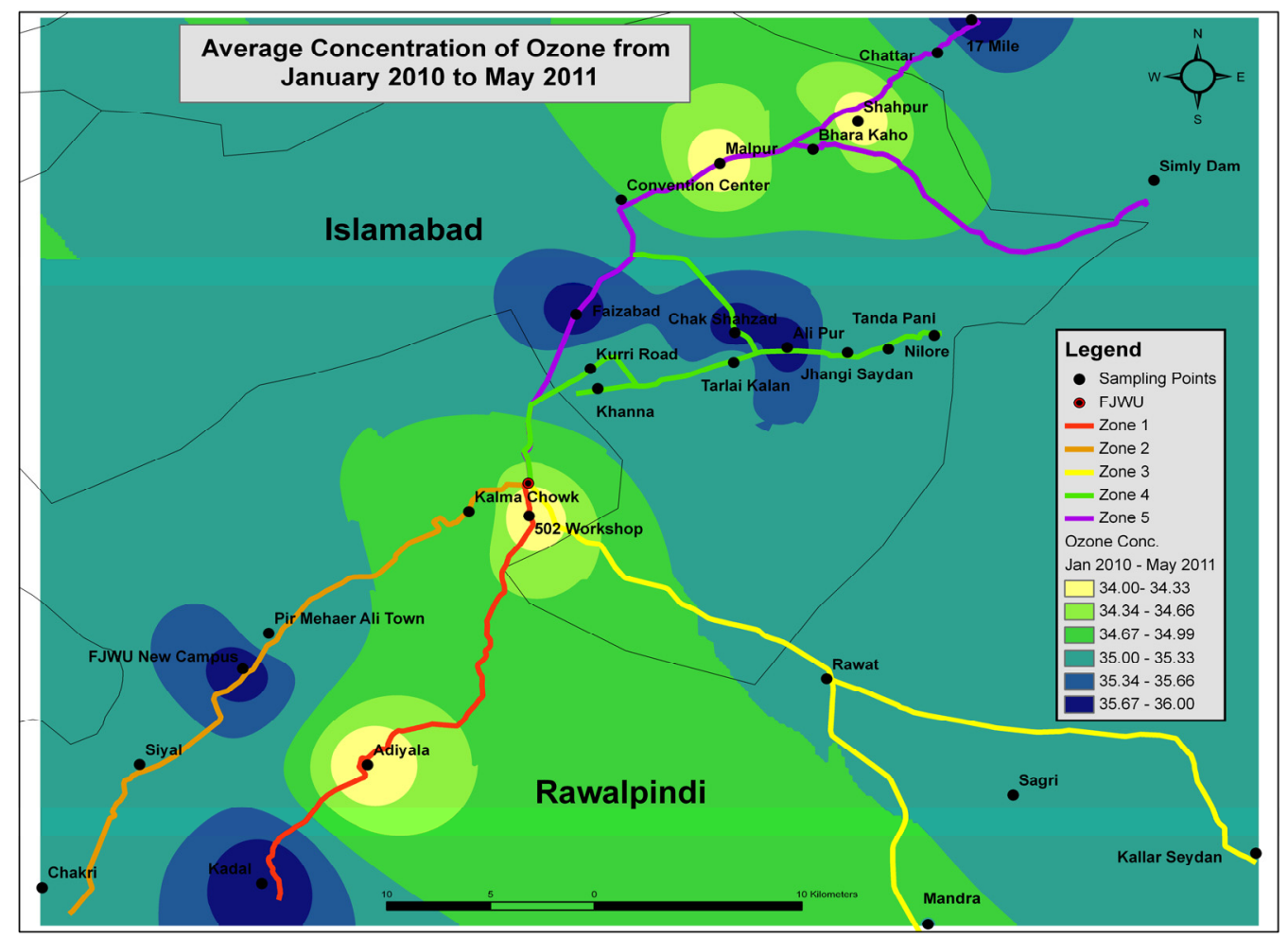

Figure 4. Spatial Interpolation of Ozone in study area (January 2010 - May 2011)

Interpolation map clearly depicts the areas of higher and lower concentration level of $\mathrm{O}_{3}$ in Rawalpindi and Islamabad. Darker color depicts the higher concentration areas while the lighter color indicates the lower concentrations. Elevated levels of $\mathrm{O}_{3}$ can be attributed to the intense traffic flow and congestion. Traffic growth rate is extremely high in twin cities. Traffic congestion is continuously increasing with this growing vehicle population leading to the highest emission rates per vehicle. Rawalpindi show high concentration levels of both the pollutants than Islamabad. This because the road network of twin cities is quite different. Islamabad is planned city with wide and extensive road network laid on the grid structure, while the road network of Rawalpindi is narrow and congested; represent a spider net like structure as shown in Figure 5 (Ministry of Communication of Pakistan and Scandia consult, 1995). Resulting in case of Islamabad pollutants get easily dispersed and diluted, while in case of Rawalpindi pollutants get more contained in the atmosphere. 
(a)

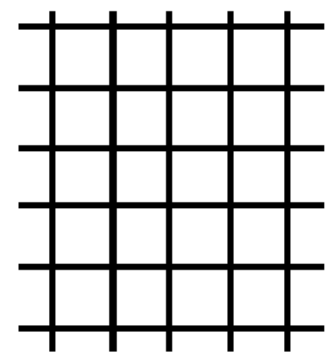

(b)

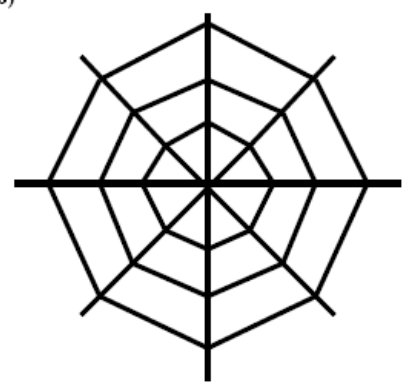

Figure 5. (a) Grid Structure (Islamabad) and (b) Spider net Structure (Rawalpindi) (Source: Ministry of Communication of Pakistan and Scandia consult, 1995)

Comparison of ozone concentration levels mentioned in Table 1-5 with the World Health Organization (WHO) standards i.e. $75 \mathrm{ppb}$ shows that values of $\mathrm{O}_{3}$ obtained are under the WHO standards. But still due to increase in $\mathrm{O}_{3}$ precursors the $\mathrm{O}_{3}$ levels are continuously increasing. So Pakistan being an agriculture country need to take appropriate steps before it reaches the alarming levels and become a serious hazard for human health, agriculture sector and environment.

\section{Conclusion}

The present research study highlights the importance of air quality management. It is concluded that $\mathrm{O}_{3}$ concentration has been increasing day by day. $\mathrm{O}_{3}$ was more in Rawalpindi as compared to Islamabad. Spatial interpolation showed variations graphically in $\mathrm{O}_{3}$ concentration at different sampling sites of twin cities in different months. Correlation analysis showed significant association of $\mathrm{O}_{3}$ concentration with climatic variables. Through present research work hot spots of $\mathrm{O}_{3}$ in twin city have been identified and this work will be helpful in future for calculation of $\mathrm{O}_{3}$ in atmosphere and for drawing spatial interpolation of $\mathrm{O}_{3}$. Moreover study highlights the areas of high concentration to control it before it increase above alarming levels.

\section{Acknowledgement}

Thanks to Higher Education Commission (HEC) of Pakistan for providing the research grant for the study under NRPU Program.

\section{References}

Afshar, H., \& Delavar, M. R. (2007). A GIS-based air pollution modeling in Tehran. Environmental Informatics Archives, 5, 557-566.

Ahmad, S.S., Biiker, P., Emberson, L., \& Shabbir, R. (2011). Monitoring nitrogen dioxide levels in urban areas in Rawalpindi, Pakistan. Water Air and Soil Pollution, 220(1-4), 141-150. http://dx.doi.org/10.1007/s11270-011-0741-9

Ashmore, M. R. (2005). Assessing the future global impacts of ozone on vegetation. Plant Cell and Environment, 28, 949-964. http://dx.doi.org/10.1111/j.1365-3040.2005.01341.x

Ashmore, M. R. Marshall, F. M., \& Wahid, A. (1998). Direct impacts of pollutant gases on crops and forests. In L. D. Ashmore, \& M. R. Emberson (Eds.). Regional air pollution in developing countries (21-33). Sweden: Swedish Environmental Development Authority.

Atkins, D. H. F., Lee, D. S. (1995). Spatial and temporal variation of rural nitrogen dioxide concentration across $\begin{array}{llll}\text { the United Kingdom. } & \text { Atmospheric 223-239. }\end{array}$ http://dx.doi.org/10.1016/1352-2310(94)00229-E

Aunan, K., Berntsen, T. K., \& Seip, H. M. (2000). Surface ozone in China and its possible impact on agricultural crop yields. Ambio, 29, 294-301.

Barnes, J., Parsons, B., \& Salter, L. (2005). GIS mapping of nitrogen dioxide diffusion tube monitoring in Cornwall UK. Air Pollution, 13, 157-166. http://dx.doi.org/10.2495/AIR050171

Calatayud, V., Marco, F., Cerveró, J., Sánchez-Peña, G., \& Sanz, M. J. (2010). Contrasting ozone sensitivity in related evergreen and deciduous shrubs. Environmental Pollution, 158, 3580-3587. http://dx.doi.org/10.1016/j.envpol.2010.08.013 
Cape, J. N. (2008). Surface ozone concentrations and ecosystem health: Past trends and a guide to future projections. Science of the Total Environment, 400(1-3), 257-269. http://dx.doi.org/10.1016/j.scitotenv.2008.06.025

Chan, A. T., So, E. S. P., \& Samad, S. C. (2001). Strategic guidelines for street canyon geometry to achieve sustainable street quality. Atmospheric Environment, 35, 5681-5691. http://dx.doi.org/10.1016/S1352-2310 (01)00212-6

Chen, J., Wang, W., Zhang, J., Liu, H., Ren, L., Liu, X., Zhang, W., \& Wang, X. (2009). Characteristics of gaseous pollutants near the main traffic line in Beijing and its influencing factors. Atmospheric Research, 94, 470-480. http://dx.doi.org/10.1016/j.atmosres.2009.07.008

Coyle, M., Fowler, D., \& Ashmore, M. (2003). New directions: implications of increasing tropospheric background ozone concentrations for vegetation. Atmospheric Environment, 37, 153-154. http://dx.doi.org/10.1016/S1352-2310(02)00861-0

Elbir, T., Mangir, N., Kara, M., Simsir, S., Eren, T., \& Ozdemir, S. (2010). Development of a GIS-based decision support system for urban air quality management in the city of Istanbul. Atmospheric Environment, 44, 441-454. http://dx.doi.org/10.1016/j.atmosenv.2009.11.008

ESRI. (2007). GIS for Air quality. ESRI, New York, USA. Retrieved from http://www.esri.com/library/bestpractices/air-quality.pdf.

Fuhrer, F. (2000). Introduction to the special issue on ozone risk analysis for vegetation in Europe. Environmental Pollution, 109, 359-360. http://dx.doi.org/ 10.1016/S0269-7491(00)00039-7

Fuhrer, J. (2009). Ozone risk for crops and pastures in present and future climates. Naturwissenschaften, 96, 173-194. http://dx.doi.org/10.1007/s00114-008-0468-7

Ghauri, B., Lodhi, A., \& Mansha, M. (2007). Development of baseline (air quality) data in Pakistan. Environmental Monitoring and Assessment, 127, 237-252. http://dx.doi.org/10.1007/s10661-006-9276-8

Jensen, S. S. (1998). Mapping human exposure to traffic air pollution using GIS. Journal of Hazardous Materials, 61(1-3), 385-392. http://dx.doi.org/10.1016/S0304-3894 (98)00139-3

Kim, J. J., Smorodinsky, S., Lipsett, M., Singer, B. C., Hodgson, A. T., \& Ostro, B. (2004). Traffic-related air pollution near busy roads. American Journal of Respiratory and Critical Care Medicine, 170, 520-526. http://dx.doi.org/10.1164/rccm.200403-2810C

Markovic, D. M., Markovic, D. A., Jovanovic, A., Lazic, L., \& Mijic, Z. (2008). Determination of $\mathrm{O}_{3}, \mathrm{NO}_{2}, \mathrm{SO}_{2}$, $\mathrm{CO}$ and $\mathrm{PM}^{10}$ measured in Belgrade urban area. Environmental Monitoring and Assessment, 145, 349-359. http://dx.doi.org/10.1007/s10661-007-0044-1

Martin, P., Cabañas, B., Villanueva, F., Gallego, M. P., Colmenar, I., \& Salgado, S. (2010). Ozone and nitrogen dioxide levels monitored in an urban area (Ciudad Real) in Central-southern Spain. Water Air and Soil Pollution, 208(1-4), 305-316. http://dx.doi.org/10.1007/s11270-009-0168-8

Percy, K. E., \& Ferretti, M. (2004). Air pollution and forest health: toward new monitoring concepts. Environmental Pollution, 130, 113-126. http://dx.doi.org/10.1016/j.envpol.2003.10.034

Pinto, D. M., Blande, J. D., Souza, S. R., Nerg, A. M., \& Holopainen, J. K. (2010). Plant volatile organic compounds (VOCs) in ozone $\left(\mathrm{O}_{3}\right)$ polluted atmospheres: The ecological effects. Journal of Chemical Ecology, 36(1), 22-34. http://dx.doi.org/10.1007/s10886-009-9732-3

Shan, W., Yin, Y., Zhang, J., Ji, X., \& Deng, X. (2009). Surface ozone and meteorological conditions in a single year at an urban site in Central eastern China. Environmental Monitoring and Assessment, 151, 127-141. http://dx.doi.org/10.1007/s10661-008-0255-0

Sheikh, I. M., Pasha, M. K., Williams, V. S., Raza, S. Q., \& Khan, K. S. A. (2007). Environmental geology of the Islamabad-Rawalpindi Area, Northern Pakistan. Geological Survey of Pakistan. Bulletin, 2078(G), 1-2.

Sitch, S., Cox, P. M., Collins, W. J., \& Huntingfor, D. C. (2007). Indirect radiative forcing of climate change through ozone effects on the land-carbon sink. Nature, 448, 791-794. http://dx.doi.org/10.1038/nature06059

The Royal Society. (2008). Ground-level ozone in the 21st century: future trends, impacts and policy implications. Science Policy. Report 15/ 08, Retrieved from http://royalsociety.org/displaypagedoc.asp?id=31506.

Veen, A. V. D., Briggs, D. J., Collins, S., Elliott, S., Fischer, P., Kingham, S., Lebret, E., Pryl, K., Reeuwijk, H. 
V., \& Smallbone, K. (2010). Mapping urban air pollution using GIS: a regression-based approach. International Journal of Geographical Information Science, 11(7), 699-718. http://dx.doi.org/10.1080/136588197242158

Vienneau, D., de Hoogh, K., \& Briggs, D. (2009). A GIS-based method for modeling air pollution exposures across Europe. Science of the Total Environment, 408, 255-266. http://dx.doi.org/10.1016/j.scitotenv.2009.09.048

Vingarzan, R. (2004). A review of surface ozone background levels and trends. Atmospheric Environment, 38, 3431-3442. http://dx.doi.org/10.1016/j.atmosenv.2004.03.030

Wahid, A. (2006a). Productivity losses in barley attributable to ambient atmospheric pollutants in Pakistan. Atmospheric Environment, 40(28), 5342-5354. http://dx.doi.org/10.1016/j.atmosenv.2006.04.050

Wahid, A. (2006b). Influence of atmospheric pollutants on agriculture in developing countries: a case study with three new varieties in Pakistan. Science of the Total Environment, 37(1-3), 304-313. http://dx.doi.org/10.1016/j.scitotenv.2006.06.017

Wahid, A., Maggs, R., Shamsi, S. R. A., Bell, J. N. B., \& Ashmore, M. R. (1995a). Air pollution and its impact on wheat yield in the Pakistan, Punjab. Environmental Pollution, 88, 147-154. http://dx.doi.org/10.1016/0269-7491(95)91438-Q

Wahid, A., Maggs, R., Shamsi, S. R. A., Bell, J. N. B., \& Ashmore, M. R., (1995b). Effects of air pollution on rice yield in the Pakistan, Punjab. Environmental Pollution, 90, 323-329. http://dx.doi.org/10.1016/0269-7491(95)00024-L,

Wahid, A., Milne, E., Marshall, F. M., \& Shamsi, S. R. A. (1997). Impact and costs of air pollution on agricultural crops in developing countries. Final Technical Report. British ODA Res. Pro. No. 1298. Department of Botany, University of the Punjab, Lahore. Pakistan.

Wahid, A., Milne, E., Shamsi, S. R. A., Ashmore, M. R., \& Marshall, F. M. (2001). Effects of oxidants on soybean growth and yield in the Pakistan, Punjab. Environmental Pollution, 113, 271-280. http://dx.doi.org/10.1016/S0269-7491(00)00190-1

Wald, L., \& Basly, L. (1998). Satellite data for the air pollution mapping. 18th EARSeL Symposium on operational remote sensing for sustainable development. Enschede, Netherlands, 133-139.

Ministry of Communication of Pakistan and Scandia consult. (1995). Greater Islamabad/Rawalpindi Area Transportation Study (GIRATS): Executive Summary. Retrieved from www.contrans.se/GIRATSsummary.pdf 